\title{
The Impact of Social Identity and Empathy on Helping Behavior: The Moderator Role of Empathy
}

\author{
Elvan Kiremitci Canioz (Corresponding author) \\ Gumushane University, Department of Psychology, Turkey \\ E-mail: kiremitci.elvan@gmail.com, \\ ORCID: 0000-0003-4733-4780
}

\author{
Hamit Coskun \\ Bolu Abant Izzet Baysal University, Department of Psychology, Turkey \\ E-mail: hamitcoskun2000@gmail.com, \\ ORCID: 0000-0002-5509-8717.
}

\begin{abstract}
Social identity, empathy and helping behavior are some of the most interesting topics in psychology. It is the volunteer behavior which is shown to meet the needs of an individual is called helping behavior. Also empathy, which is one of the best predictors of prosocial behaviors, is that the individual expresses this situation by understanding feelings and thoughts. Aim of this studies are to examine the relationship between social identity, empathy and helping behavior. The sample group of the study consisted of university students in Bolu Abant Izzet Baysal University. In an experimental study, social identity manipulation was carried out in two different ways: Turkish and Syrian group. In order to measure the empathy scores of the participants, Basic Empathy Scale (TEO) was used. In the first study, the helping behavior was measured by the Help Text prepared by the researchers; in the second study, the participants were given the participant fee and the helping behaviors were measured by asking the amount of financial aid if they would give to UNICEF. When the findings were examined, only the helping behavior differed from the group according to the social identity in the first study, while in the second study that the helping behavior and empathy scores of the participants differed significantly between the groups. In addition, in both studies, empathy had a moderator role in the impact of social identity on helping behavior. It is adviced that research design can be tested with other samples.
\end{abstract}

Key Words: Social identity, empathy, helping behavior, prosocial behavior.

DOI: $10.7176 / \mathrm{JSTR} / 5-12-35$

\section{INTRODUCTION}

\subsection{Social Identity}

The individual lives in a society and his/her identity in this society is called a social identity. According to the Social Identity Theory developed by Henri Tajfel and John Turner (1979), the individual considers the people in the same group as an internal group member and the other people in the different groups as external group members. For this reason, internal group members tend to favor, attributing positive characteristics to internal group members, seeing them more similar to themselves, becoming more empathic and helping them (Tajfel \& Turner, 1979; Tajfel, 1982; Tarrant, Dazeley \& Cottom, 2009).

When the attitude of the individual towards the external group members is examined, there are many factors that affect the empathic approach and the helping behavior. First, the interaction between the individual and the other group members, the intensity and quality of this interaction affect the empathic approach and helping behavior towards the members (Johnston and Glasford, 2017; Levine, Cassidy \& Brazier, 2002). Although the individual feels guilt towards external group members, he/she is more empathic and helpful (Oswald and Harvey, 2000; van Leeuwen, van Dijk and Kaynak, 2013). The relationship between the country where the members of the external members of the individual and their own countries affect especially the behavior of help (James \& Zagefka, 2017).

Some studies in which the helping behavior and empathy were examined on the basis of the group showed that the internal group nepotism was not correct. For example; In a study by Sierksma, Thijs and 
Verkuyten (2014), the helping behaviors of children aged between 8 and 13 years were examined for the internal and external group members. In another study that examined empathy for external group members, it was concluded that empathy was effective only when assisting internal group members (Stürmer et al., 2006).

\subsection{Empathy}

It is called empathy when the individual expresses this situation by understanding the feelings and thoughts of another person. Interpersonal relations are organized through empathy, one of the most important factors affecting communication. Therefore, empathy is considered to be one of the best predictors of prosocial behaviors such as help (Atkins, Hart \& Donnelly, 2004; Feddes, Mann \& Doosje, 2015; Welp \& Brown, 2014). It has been proven by many research findings that individuals help people more empathically approaching (Light et al., 2015; Paciello et al., 2013; Richman, DeWall \& Wolff, 2015; Spinrad et al., 2006; Stürmer et al., 2006).

Studies in the field of psychology indicate that empathy is predictive of helping behavior, but also shows the effect of some variables such as feeling responsibility. For example; according to the norm of responsibility from social norms, the individual feels the responsibility and helps more, even if the person in need of assistance is an external group member (Basil, Ridgway \& Basil, 2006).

When the literature is examined, it is known that empathy is one of the most important variables that affect the helping behavior, and it is known that the individual feels a responsibility for another person to help and act with his / her will to increase this helping behavior (Pavey, Greitemeyer \& Sparks, 2012). If the individual in need of help is a member of the external group, the individual's sense of responsibility and the empathy towards that situation also increases the behavior of the helper (Zebel, Doosje \& Spears, 2009).

\subsection{Helping Behavior}

It is very important that an individual living in a society establish healthy relationships with others. The helping behavior as one of the prosocial behaviors that strengthen interpersonal relationships is expressed as the voluntary behavior of the individual towards meeting the needs of another (Jolliffe \& Farrington, 2006; Oarga, Stavrova \& Fetchenhauer, 2015).

The importance of empathy is due to the fact that it is one of the variables that best predicts the behavior of the individual. The individual tends to help more empathically to those whom he or she approaches, and this information is consistent with Social Identity Theory. The individual is more empathetic and more helpful because he/she feels more closeness to the people in the same group (Paciello et al., 2013; Tajfel \& Turner, 1979; Tajfel, 1982).

The behavior is done in two ways as material and spiritual. Because it is much easier to make spiritual aid, it is more than financial aid. Research on financial aid argues that concrete support should be expressed in particular for the purpose of increasing financial aid (Atkins, Hart \& Donnelly, 2004, Diener \& Tay, 2017).

In these two experimental studies, the effects of empathy and helping behaviors on social identity and the effect of social identity on the helping behavior of social identity were examined and it was seen that empathy had a regulatory role in this effect.

\section{I. Experiment}

\subsection{METHOD}

\subsubsection{Participants}

As a sample group, 120 university students from Bolu Abant Izzet Baysal University participated in the study. The sample group included 100 females and 20 male students. The mean age of the participants was $X=20.33$ (S.D. $=1.57$ ). They are also given extra course points for their participation.

\subsubsection{Data Collection Tools}

\subsubsection{Social Identity}

In order to perform social identity manipulation, scales prepared according to 2 different conditions were applied to the participants. In the first condition, a Turkish university student was given a photograph of this student and they were asked to write and evaluate the situation of this student for 2 minutes. In addition, a text describing the situation of a Turkish university student in need of assistance was given. In the second condition, a photograph of a Syrian university student was given and they were expected to evaluate the situation of this student for 2 minutes, then they were asked to read a text describing the situation of a Syrian student who needed help. 
Especially as a member of the Syrian group's foreign group was selected because, as a victim of war is a time in Turkey and living in society are exposed to positive and negative attitudes.

\subsubsection{Basic Empathy Scale (BES)}

In order to measure the concept of empathy in the study, Basic Empathy Scale (BES), which was developed by Jolliffe and Farrington (2006) and adapted to Turkish by Topcu, Erdur-Baker and CapaAydin (2016), was used. The scale consists of 20 items in total and 5 points in Likert type. 9 items of the scale measure cognitive empathy and 11 items measure emotional empathy. In addition, the Cronbach Alpha reliability coefficient of this scale was .77.

\subsubsection{The Help Text}

The aid text prepared by the researchers was used to examine the helping behaviors of the participants. In the text, the status of a university student who has been saving 500 Turkish Liras (TL) for a long time for his brother's need and losing this money is detailed. The rest of the text was asked how much to share with him, even if the individual had the amount they needed. In the help text, 500 Turkish Liras (TL) was asked from 0 to 500 as 11-point Likert type. The help behavior of the individual is measured according to the given quantity response.

\subsubsection{Demographic Information Form}

Participants were given a demographic information form in which they were asked about their personal information such as gender, age, place of birth, educational status, income status and whether they participated in an experimental study before.

In addition, on the first page of the scale, it was stated that they could voluntarily participate in the study and leave it if they wanted.

\subsubsection{Process and Analysis}

Participants were recruited in groups of four to laboratory and the participants were randomly assigned to each experimental condition. In the laboratory environment, work was carried out with the control of the researcher by placing them in distant desks. In addition, in order to neutralize pre-manipulation, participants were asked to draw a map of the campus of Bolu Abant Izzet Baysal University and the manipulation was made after this application.

The findings were analyzed with SPSS 21.0 analysis program. Correlation, independent groups t-test and regulatory analysis were performed. In addition, the power of the research was found as .98. For these researches, there is not any funding.

\subsection{RESULTS}

\subsubsection{Investigation of Helping Behavior and Empathy Variables by Social Identity}

In order to determine whether the help behavior and empathy variables differ according to Turkish and Syrian university students' conditions, Independent Groups T Test analysis was applied by the researcher. According to the results of the analysis, it was seen that the help behavior was significantly different in both conditions, but the empathy scores did not differ.

Table 1. Analysis of empathy and helping behavior according to social identity conditions

\begin{tabular}{|llllll|}
\hline & Turkish & Syrian & T & Df & p \\
\hline $\begin{array}{l}\text { Helping } \\
\text { Behavior }\end{array}$ & 263.79 & 363.71 & -4.11 & 117.85 & $.00^{* *}$ \\
& $(126.28)$ & $(140.01)$ & & & \\
Empathy & 64.48 & 66.27 & -.84 & 117.87 & .40 \\
& $(11.07)$ & $(12.24)$ & & & \\
& & & & & \\
\hline
\end{tabular}

$* \mathrm{p}<.05, * * \mathrm{p}<.01$

When the helping behavior was examined, it was seen that the participants in the Syrian student condition $(\mathrm{X}=363.71, \mathrm{SD}=140.01)$ helped more than the participants in the Turkish student condition $(\mathrm{X}=$ 
263.79, SD = 126.28). In terms of empathy, there was no significant difference between the participants' empathy scores.

\subsubsection{Examining the Effect of Social Identity and Empathy on the Helping Behavior}

Organizational analysis (multi-linear regression) was applied to examine the role of empathy in the impact of social identity on the help behavior. When the findings are examined, it is seen that social identity and empathy have a significant common effect on help behavior and empathy has a role in the effect of social identity on the helping behavior.

Table 2: Interaction of Social Identity and Empathy

\begin{tabular}{|c|c|c|c|c|c|c|c|}
\hline \multirow{2}{*}{$\begin{array}{l}\text { Model } \\
\text { Variables }\end{array}$} & \multirow[t]{2}{*}{$b$} & \multirow[t]{2}{*}{ SH } & \multirow[t]{2}{*}{$t$} & \multirow[t]{2}{*}{$p$} & \multicolumn{2}{|c|}{$\% 95 C I$} & \multirow[t]{2}{*}{$R^{2}$} \\
\hline & & & & & Low $B$. & $U p S$. & \\
\hline $\begin{array}{l}\text { Predictive } \\
\text { Variables }\end{array}$ & 773.80 & 223.11 & 3.46 & .00 & 331.10 & 1216.50 & \\
\hline (Constant) & & & & & & & \\
\hline $\begin{array}{l}\text { Basic } \\
\text { Effects }\end{array}$ & -280.11 & 137.15 & -2.04 & .04 & -551.76 & -8.48 & \\
\hline $\begin{array}{l}\text { Social } \\
\text { Identity }\end{array}$ & -9.39 & 3.40 & -2.76 & .00 & -16.13 & -2.66 & \\
\hline $\begin{array}{l}\text { 2-Way } \\
\text { Interactions }\end{array}$ & & & & & & & \\
\hline $\begin{array}{l}\text { Social } \\
\text { Identity } \\
\text { *Empathy }\end{array}$ & 5.83 & 2.07 & 2.82 & .00 & 1.73 & 9.92 & \\
\hline Model $^{\mathbf{a}}$ & & & & & & .43 & .18 \\
\hline
\end{tabular}

$* p<.05 ; p<.01 ;$ Predicted variable $=$ Helping Behavior

In order to examine this interaction in depth, the significance of the difference between the 16th (low level of empathy), the 50th (mean level of empathy) and the 84th (high level of empathy) percentages of the distribution of the regulatory variable in slope analysis was tested (Hayes). , 2013: 250). There was no significant difference between low empathy conditions $(\% \mathrm{X} \rightarrow \mathrm{Y} /(\mathrm{W}=55.36)=42.67, \mathrm{SH}=31.46$, $\mathrm{t}=1.36, \mathrm{p}=.18,95 \% \mathrm{CI}[-19.64,104.97]$, mean $(\mathrm{ucX} \rightarrow \mathrm{Y} /(\mathrm{W}=62.50)=84.30, \mathrm{SH}=24.54, \mathrm{t}=3.43$, $\mathrm{p}=.00,95 \% \mathrm{CI}[35.68,132.91]$ and high levels of empathy $(.5 \mathrm{X} \rightarrow \mathrm{Y} /(\mathrm{W}=80)=186.33, \mathrm{SH}=38.74$, $\mathrm{t}=4.81, \mathrm{p}=.00,95 \%$ CI $[109.61,263.05]$ The differences between the conditions are significant.

$$
Y=b_{0}+b_{1} W_{\text {empathy }}+b_{2} D_{\text {identity }}+b_{3} D_{\text {identity }} W_{\text {empathy }}
$$




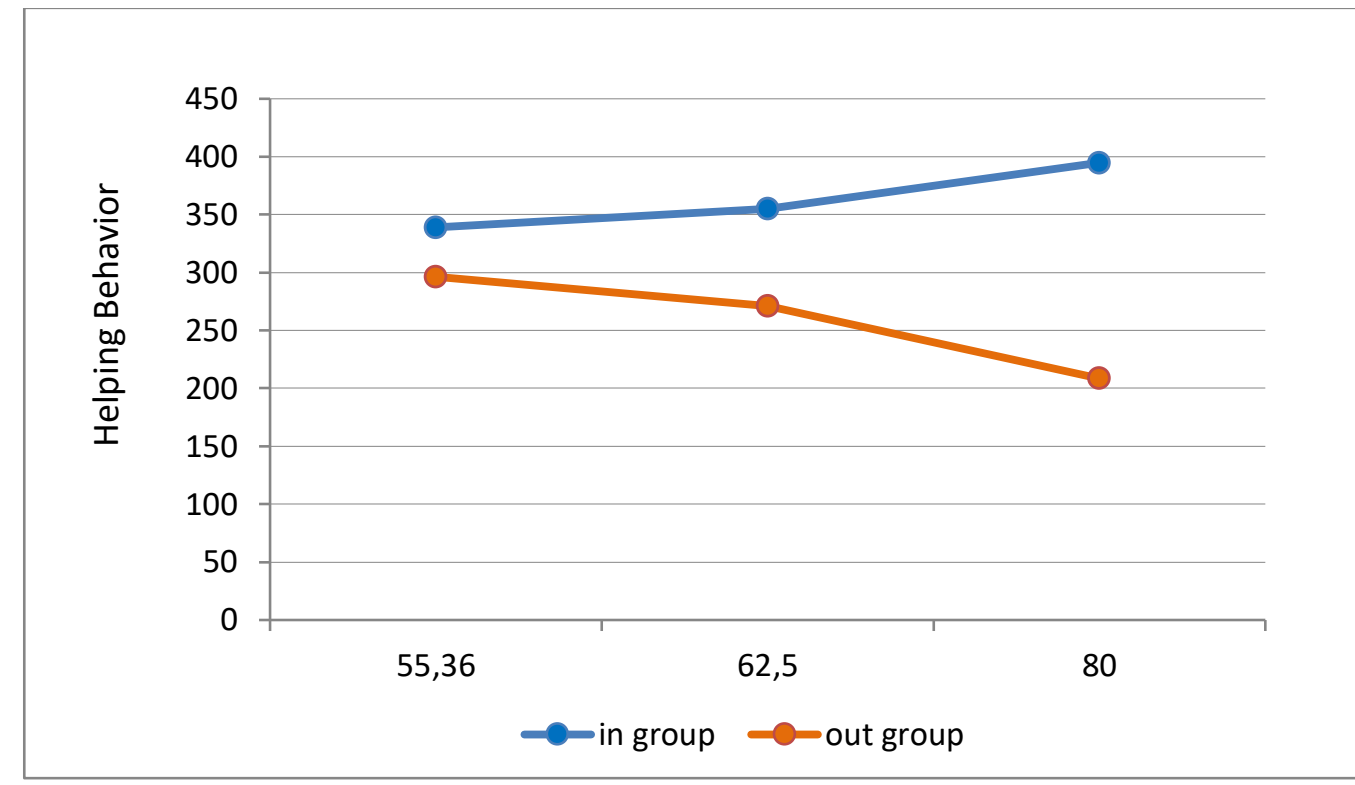

When the findings are examined, social identity does not significantly affect the help behavior of the participants with low empathy. However, in the participants with moderate and high level of empathy, social identity significantly affects the help behavior.

\subsection{DISCUSSION}

When the research findings were examined, it was seen that only the helping behaviors of the participants differed according to the social identity and there was no significant difference for empathy between the groups. Furthermore, it was observed that the participants were more helpful than the Turkish student condition when the Syrian student, who is an external group member, needed help. Finally, the results were obtained in this direction because the helping behavior in this study was measured only in the text. According to the information in the literature, individuals tend to be more empathic and more empathic towards the members of the internal group in which they belong in the same group, by showing internal group favoritism depending on the Social Identity Theory. The results of this study are not consistent with the literature. However, when the findings are considered in detail, we can have a collectivist culture and the findings can be explained by many other theories (Dovidio et al., 1997; Levine, Cassidy \& Brazier, 2002; Paciello et al., 2013; Tajfel, 1982). First of all, Syrian are Muslim as we are and we are in a same group about religion. Also, the norm of responsibility, especially of social norms, tells us that it needs to be helped. It can be explained within the framework of the norm of responsibility, to be helpful to a community who escaped from the war environment and to take refuge in our country, to be helped more in case of a need. Because we have a collectivist culture, it can be explained by the benevolence feature that individuals living in the same society choose to help the members of a war-victimized society by perceiving more victims. In addition, because of the feelings of guilt that are best predicted by the helping behavior, individuals have felt responsible and have chosen to help more than a group that is a victim of war (Oswald \& Harvey, 2000; van Leeuwen, van Dijk \& Kaynak, 2013). According to the results of the research, it was concluded that empathy has a regulatory role in the effect of social identity on help behavior. According to the information in the literature, there are many research findings indicating that it is one of the best predictors of empathic help behavior (Johnston \& Glasford, 2017; Levine, Cassidy \& Brazier, 2002). When it is examined in terms of social identity, it is seen that individuals help the members of the external group more empathically when they approach them (Sierksma, Thijs \& Verkuyten, 2014). When the individual feels responsibility towards the member, he is seen to be more empathetic and more helpful (Zebel, Doosje \& Spears, 2009).

\section{II.Experiment}

\subsection{METHOD}

318 | P a g e www.iiste.org 


\subsubsection{Participants}

The sample group consisted of 78 female and 16 male, totally 94 students. The students continue their undergraduate education at Bolu Abant İzzet Baysal University. Participants were randomly assigned to each condition, plus an extra course point for their participation. The mean age was 18- 27 years $(\mathrm{X}=$ $19.82, \mathrm{SD}=1.23)$.

\subsubsection{Data Collection Tools}

\subsubsection{Social Identity}

The social identity manipulation developed in the first experiment was applied to the participants in the same way. In the first condition, the participants were first photographed by a Turkish university student and they were asked to write and evaluate the situation of this student for 2 minutes. In the second case, the participants were photographed by a Syrian university student and they were expected to evaluate the situation of this student for 2 minutes.

\subsubsection{Basic Empathy Scale}

In this study, the concept of empathy is measured through the Basic Empathy Scale. 9 of the scale items are cognitive empathy and 11 are emotional empathy, and the 5-point Likert type scale consists of 20 items. The scale which was developed by Jolliffe and Farrington (2006) was adapted by Topcu, ErdurBaker and Capa-Aydin (2016). In this study, the reliability coefficient of the scale was found to be.80.

\subsubsection{The Helping Behavior}

1 Turkish Lira (TL), which consists of 10 coins to their voluntary participation in the study, was stated by the researcher before the study started. At the end of the study, UNICEF (United Nations Children's Fund) was asked to write to the relevant response area whether they would like to participate in the aid campaign organized by the researcher and if they would like to participate. The purpose of this measurement is to measure helping behaviors of participants to see whether they will share an amount they have earned for help or not to make financial additions. The values to be given in the findings are in Turkish Liras. The donor will make a donation to UNICEF with the help.

\subsubsection{Demographic Information Form}

On the first page of the scale, it was explained that they could voluntarily participate in the study and leave it if they wanted.

In the Demographic Information Form, participants were given a form in which their personal information was asked, such as gender, age, place of birth, educational status, their families and their income status and whether they participated in an experimental study before.

\subsubsection{Process and Analysis}

The research was conducted in the laboratory. In the study conducted in groups of four people, the participant groups were randomly assigned for each experimental condition. Participants were told that they would be given 1 Turkish Lira (TL) participant fee before the start of the research. In order to neutralize pre-manipulation, participants were asked to draw a map of the campus of Abant Izzet Baysal University in Bolu and the manipulation was made after this application. At the end of the study, the researcher was asked whether an aid campaign was organized on behalf of UNICEF and whether it would be financially available at the time, and if so, the amount of this aid was asked. In addition, the researcher investigated the amount of financial support from their own budgets by taking the participant fee or using them for help. The findings were examined with the help of SPSS 21.0 analysis program and the power of the research was found as .84 .

\subsection{RESULTS}

\subsubsection{Investigation of Helping Behavior and Empathy Variables by Social Identity}

Independent T test (Independent Sample T Test) analysis was performed by the researcher in order to determine whether the help behavior and empathy scores differ depending on the participants' assessment of Turkish or Syrian students. According to the results of the analysis, it was seen that the help behavior and empathy differed significantly in both conditions.

Table 3: Analysis of empathy and helping behavior according to social identity conditions 
ISSN 2422-8702 (Online), DOI: 10.7176/JSTR/5-12-35

Vol.5, No.12, 2019

\begin{tabular}{|llllll|}
\hline Variables & Turkish & Syrian & t & Df & p \\
\hline Helping Behavior & 5.00 & 2.46 & 2.96 & 74.49 & $.00^{* *}$ \\
& $(5.04)$ & $(2.97)$ & & & \\
Empathy & 70.04 & 65.51 & 2.01 & 87.55 & $.04 *$ \\
& $(12.05)$ & $(9.58)$ & & & \\
\hline$* p<.05, * * p<.01$ & & & & & \\
\hline
\end{tabular}

In terms of helping behavior, participants $(X=5.00, S D=5.04)$ provided significantly more financial support than the participants in the Syrian student condition $(X=2.46, \mathrm{SD}=2.97)(\mathrm{t}(74.49)=2.96, \mathrm{p}<$ $.01)$. In addition, it was seen that the participants in the Turkish student condition $(X=70.04, \mathrm{SD}=12.05)$ had higher empathy scores than the participants in the Syrian student condition $(X=65.51, \mathrm{SD}=9.58)$ $(\mathrm{t}(87.55)=2.01, \mathrm{p}<.05)$.

\subsubsection{Investigating the Moderator Role of Empathy}

Behavior Organizational analysis (multi-linear regression) was applied to examine the role of empathy in the impact of social identity on the helping behavior. When the findings are examined, it is seen that social identity and empathy have a significant common effect on helping behavior. According to this information, there is a moderator role of empathy in the impact of social identity on helping behavior.

Table 4: Interaction of Social Identity and Empathy

\begin{tabular}{|c|c|c|c|c|c|c|c|c|}
\hline \multirow{2}{*}{$\begin{array}{l}\text { Model } \\
\text { Variables }\end{array}$} & \multirow[t]{2}{*}{$b$} & \multirow[t]{2}{*}{ SH } & \multirow[t]{2}{*}{$t$} & \multirow[t]{2}{*}{$p$} & \multicolumn{2}{|c|}{$\% 95$ CI } & \multirow[t]{2}{*}{$\Delta R^{2}$} & \multirow[t]{2}{*}{$R^{2}$} \\
\hline & & & & & Low $B$. & $U p B$. & & \\
\hline $\begin{array}{l}\text { Predictive } \\
\text { Variables }\end{array}$ & 26.30 & 8.20 & 3.21 & .00 & 10.02 & 42.59 & & \\
\hline (Constant) & & & & & & & & \\
\hline $\begin{array}{l}\text { Basic } \\
\text { Effects }\end{array}$ & -14.20 & 5.44 & -2.61 & .01 & -25.02 & -3.38 & & \\
\hline $\begin{array}{l}\text { Social } \\
\text { Identity }\end{array}$ & -.27 & .12 & -2.32 & .02 & -.51 & -.04 & & \\
\hline Empathy & & & & & & & & \\
\hline $\begin{array}{l}\text { 2-Way } \\
\text { Interactions }\end{array}$ & .17 & .08 & 2.14 & .03 & .01 & .33 & & \\
\hline Model $^{\mathbf{a}}$ & & & & & & & .37 & .14 \\
\hline
\end{tabular}

${ }^{*} p<.05 ; p<.01$; Predicted variable $=$ Helping Behavior

In order to examine this interaction in depth, the significance of the difference between the 16th (low level of empathy), the 50th (mean level of empathy) and the 84th (high level of empathy) percentages of the distribution of the regulatory variable in slope analysis was tested (Hayes). , 2013: 250). The result of the analysis was low (ideX $\rightarrow \mathrm{Y} /(\mathrm{W}=57)=-4.45, \mathrm{SH}=1.19, \mathrm{t}=-3.75, \mathrm{p}=.00,95 \%$ CI $[-6.81$, $2.09]$ and the average level of empatide $((\mathrm{X} \rightarrow \mathrm{Y} /(\mathrm{W}=64)=-3.25, \mathrm{SH}=.90, \mathrm{t}=-3.63, \mathrm{p}=.00,95 \%$ CI [-5.03, -1.47] There are significant differences between the conditions, while the higher level is empathy $(--\mathrm{X} \rightarrow \mathrm{Y} /(\mathrm{W}=82)=-.17, \mathrm{SH}=1.46, \mathrm{t}=-.11, \mathrm{p}=.90,95 \% \mathrm{CI}[-3.07,2.72]$ The differences between the conditions are not significant.

$$
Y=b_{0}+b_{1} W_{\text {empathy }}+b_{2} D_{\text {identity }}+b_{3} D_{\text {identity }} W_{\text {empathy }}
$$

Graphic 2: Low, Medium and High Empathic Participants 


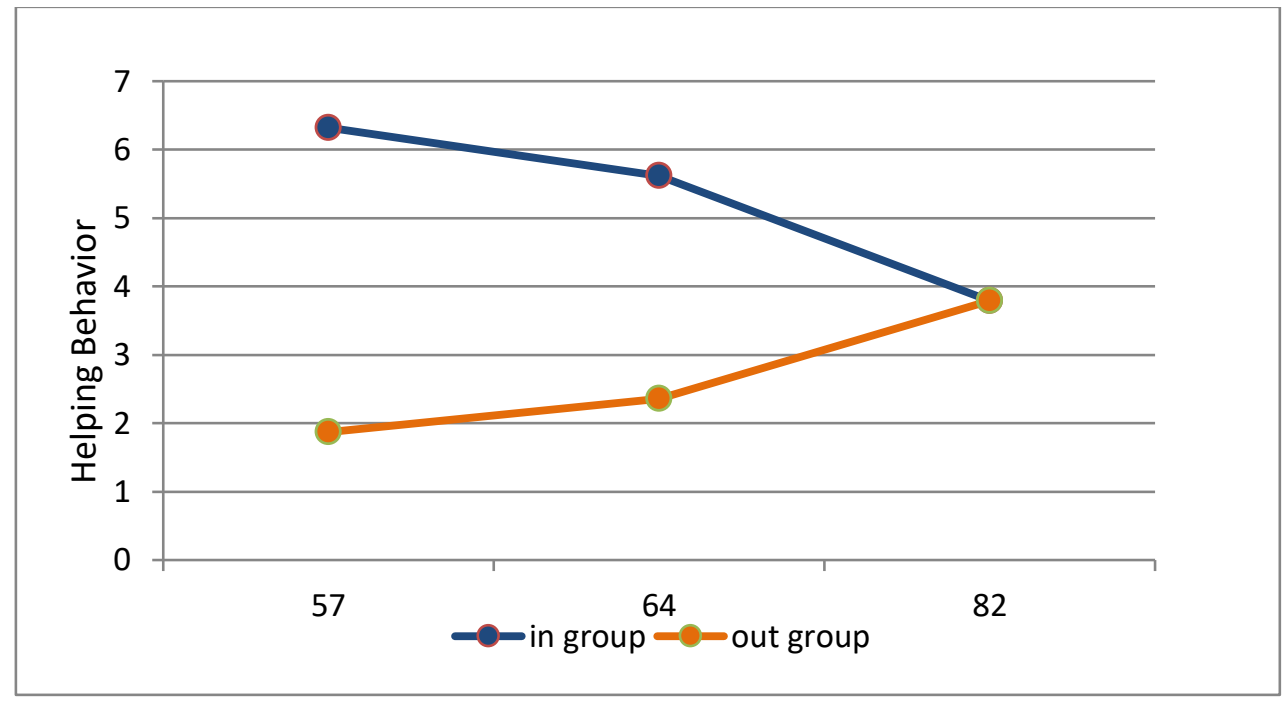

When the findings are examined, social identity significantly affects the behavior of the participants with low and moderate empathy. However, in high-level participants, social identity does not significantly affect helping behavior.

\subsection{DISCUSSION}

When the research findings were examined, it was found that the helping behavior and empathy scores differed significantly between the groups according to the social identity condition, and the participants in the Turkish manipulation condition were significantly more financially supportive and had higher empathy scores than the participants in the other condition. As the helping behavior in this study was measured behaviorally by real money, the findings were found to be different from the first study.

The findings of this study and the findings of Social Identity Theory are consistent. When individuals measured their aids in a behavioral way, they chose to make more financial support to their groups and were empathetic. Individuals tend to favor the members of the inner group of the same group, and therefore tend to be more helpful and empathic. The results were found to be consistent with the literature in this respect (Tajfel \& Turner, 1979; Tajfel, 1982; Welp \& Brown, 2014).

According to another finding, social identity has an impact on aiding behaviors and it has been seen that empathy has a moderator role. When the field information is examined, many research findings are found indicating that individuals are affected by the social identity of the needy while helping and that there are positive and meaningful relationships between empathy and helping behavior (Eisenberg, Zhou \& Koller, 2001; Johnston \& Glasford, 2017; Oswald \& Harvey, 2000; Sierksma, Thijs \& Verkuyten, 2014; Tajfel \& Turner, 1979; Tarrant, Dazeley \& Cottom, 2009). All these findings are consistent with research findings.

\section{CONCLUSION}

In this study, the effect of social identity on the helping behavior and the moderator role of empathy in this effect were examined through two experimental studies. In the first study, helping behavior was measured by the text prepared by the researcher, and in the second study, behavioral assistance was measured by means of participant wages and tangible money. In this respect, there are very few studies in the literature that make comparisons between groups with similar patterns. In addition, this study has an important place in literature because it is not a study examining social identity, empathy and helping behavior variables in the same pattern in terms of Turkish and Syrian groups.

In addition, since there is a significant intergroup difference in terms of helping behavior and empathy, it is possible to say that the attitudes of the individual who needs need change depending on the group they belong to, while the participants are helping and empathizing with the individual. In future research, it is recommended that social identity, empathy and helping variables should be elaborated in researches through newly developed manipulations, and the new groups should be added to repeat the research.

\section{REFERENCES}

Atkins, R., Hart, D. \& Donnelly, T. M. (2004). Moral identity development and school attachment. Moral development, self, and identity, 65-82. Doi: 10.4324/9781410610256. 
, No.12, 2019

Basil, D. Z., Ridgway, N. M. \& Basil, M. D. (2006). Guilt appeals: The mediating effect of responsibility. Psychology \& Marketing, 23(12), 1035-1054. Doi: 10.1002/mar.200xx.

Diener, E. \& Tay, L. (2017). A scientific review of the remarkable benefits of happiness for successful and healthy living. Happiness, 90.

Dovidio, J. F., Gaertner, S. L., Validzic, A., Matoka, K., Johnson, B. \& Frazier, S. (1997). Extending the benefits of recategorization: Evaluations, self-disclosure, and helping. Journal of Experimental Social Psychology, 33(4), 401-420. Doi: 10.1006/jesp.1997.1327.

Eisenberg, N., Zhou, Q. \& Koller, S. (2001). Brazilian adolescents' prosocial moral judgment and behavior: Relations to sympathy, perspective taking, gender-role orientation, and demographic characteristics. Child development, 72(2), 518-534. Doi: 10.1111/1467-8624.00294.

Feddes, A. R., Mann, L. \& Doosje, B. (2015). Increasing self-esteem and empathy to prevent violent radicalization: a longitudinal quantitative evaluation of a resilience training focused on adolescents with a dual identity. Journal of Applied Social Psychology, 45(7), 400-411. Doi: $10.1111 /$ jasp.12307.

James, T. K. \& Zagefka, H. (2017). The importance of national identities and intergroup relations in disaster aid. In Intergroup Helping, 269-285. Springer.

Jolliffe, D. \& Farrington, D. P. (2006). Development and validation of the Basic Empathy Scale. Journal of adolescence, 29(4), 589-611. Doi: $\quad$ 10.1016/j.adolescence.2005.08.010.

Johnston, B. M. \& Glasford, D. E. (2017). Intergroup contact and helping: How Quality contact and empathy shape outgroup helping. Group Processes \& Intergroup Relations, Doi: $10.1177 / 1368430217711770$

Levine, M., Cassidy, C., Brazier, G. \& Reicher, S. (2002). Self-Categorization and Bystander Non intervention: Two Experimental Studies 1. Journal of Applied Social Psychology, 32(7), 14521463. Doi: 10.1111/j.1559-1816.2002.tb01446.x.

Light, S. N., Moran, Z. D., Swander, L., Le, V., Cage, B., Burghy, C., ... \& \& Davidson, R. J. (2015). Electromyographically assessed empathic concern and empathic happiness predict increased prosocial behavior in adults. Biological psychology, 104, 116-129. Doi: 10.1016/j.biopsycho. 2014.11.015.

Oarga, C., Stavrova, O. \& Fetchenhauer, D. (2015). When and why is helping others good for wellbeing? The role of belief in reciprocity and conformity to society's expectations. European Journal of Social Psychology, 45(2), 242-254. Doi:10.1002/ejsp.2092.

Oswald, D. L. \& Harvey, R. D. (2000). Hostile environments, stereotype threat, and math performance among undergraduate women. Current Psychology, 19(4), 338-356. Doi: 10.1007/s12144-000-1025-5.

Paciello, M., Fida, R., Cerniglia, L., Tramontano, C. \& Cole, E. (2013). High cost helping scenario: The role of empathy, prosocial reasoning and moral disengagement on helping behavior. Personality and Individual Differences, 55(1), 3-7. Doi:10.1016/j.paid.2012.11.004.

Pavey, L., Greitemeyer, T. \& Sparks, P. (2012). "I help because I want to, not because you tell me to" empathy increases autonomously motivated helping. Personality and Social Psychology Bulletin, 38(5), 681-689. Doi: 10.1177/0146167211435940.

Richman, S. B., DeWall, C. N. \& Wolff, M. N. (2015). Avoiding affection, avoiding altruism: Why is avoidant attachment related to less helping?. Personality and Individual Differences, 76, 193197. Doi: 10.1016/j.paid.2014.12.018. 
Spinrad, T. L., Eisenberg, N., Cumberland, A., Fabes, R. A., Valiente, C., Shepard, S. A., ...\& Guthrie, I. K. (2006). Relation of emotion-related regulation to children's Social competence: A longitudinal study. Emotion, 6(3), 498. Doi: 10.1037/1528 3542.6.3.498.

Sierksma, J., Thijs, J. \& Verkuyten, M. (2014). Children's intergroup helping: The role of empathy and peer group norms. Journal of Experimental Child Psychology, 126, 369 383. Doi: 10.1016/j.jecp.2014.06.002.

Stürmer, S., Snyder, M., Kropp, A. \& Siem, B. (2006). Empathy-motivated helping: The moderating role of group membership. Personality and Social Psychology Bulletin, 32(7), 943-956. Doi: $10.1177 / 0146167206287363$.

Tajfel, H. \& Turner, J. C. (1979). An integrative theory of intergroup conflict. The Social psychology of intergroup relations, 33(47), 74.

Tajfel, H. (1982). Social psychology of intergroup relations. Annual review of psychology, 33(1), 139. Doi: 10.1146/annurev.ps.33.020182.000245.

Tarrant, M., Dazeley, S. \& Cottom, T. (2009). Social categorization and empathy foroutgroup members. British Journal of Social Psychology, 48(3), 427-446. Doi: 10.1348/ 014466608 X373589.

Topçu, Ç., Baker, Ö. E. \& Aydın, Y. Ç. (2016). Temel empati ölçeği Türkçe uyarlaması: geçerlik ve güvenirlik çalışması. Türk Psikolojik Danışma ve Rehberlik Dergisi, 4(34).

van Leeuwen, E., van Dijk, W. \& Kaynak, Ü. (2013). Of saints and sinners: How appeals to collective pride and guilt affect outgroup helping. Group Processes \& Intergroup Relations, 16(6), 781796. Doi: $10.1177 / 1368430213485995$.

Welp, L. R. \& Brown, C. M. (2014). Self-compassion, empathy, and helping intentions. The Journal of Positive Psychology, 9(1), 54-65. Doi: 10.1080/17439760.2013.831465.

Zebel, S., Doosje, B. \& Spears, R. (2009). How perspective-taking helps and hinders group based guilt as a function of group identification. Group Processes \& Intergroup Relations, 12(1), 6178. Doi: $10.1177 / 1368430208098777$.

Author's Note: This study was produced from Elvan Kiremitçi Canı̈z's PhD thesis. 